\title{
Олефиренко С.П. \\ О необходимости законодательной корректировки понятия «пассажир» в тексте Устава железнодорожного транспорта Российской Федерации
}

колледж железнодорожного транспорта, Уральский государственный университет путей сообщения (Россия, Екатеринбург)

doi:10.18411/spc-20-11-2017-11

idsp: 000001:spc-20-11-2017-11

Abstract

The investigation in force charter railways transport Russian Federative, of frame legislative notion "passenger". Learn flgoritm railways passengers transports in relations passengers of participants transports process legislative level. The examination opinion in Russians scientifics semaciologi in etymology notion " passenger". The paper suspend examplejudge dicide - precedent of wording invectigation notion.

Express sentence in new editorial legislative notions "passengers" of "passengers railways transports" in force charter railways transport Russian Federative, binding it is necessity correctors essence notion, of rise quality execution professionals problems workers railways transport in legal organs Russian.

Впервые в истории перевозка людей и багажа средствами железнодорожного транспорта была осуществлена 15 сентября 1830 года на железнодорожной линии Ливерпуль - Манчестер в Великобритании с вокзала «Ливерпул роуд стейшен».

30 октября (11 ноября) 1837 года открыта первая в России железная дорога «общего пользования» Петербург - Царское Село с продолжением до Павловска, 27 километров, где прозвучало среди присутствующих, новое слово - понятие «пассажир», которое относилось К лицам, совершившим проезд по новой российской императорской железной дороге.

Вопросы регламентации юридического понятия «пассажир» в транспортном законодательстве Российской империи будет рассмотрено в отдельной статье.

В период с 1917 года по настоящее время, законодателем было принято девять Уставов железнодорожного транспорта страны, в восьми из них исследуемое понятие законодательно не закреплено.

В ныне действующей статье 2, редакции Устава железнодорожного транспорта Российской Федерации, 2003 года (далее - Устав), законодателем новеллой было определено, что пассажир - физическое лицо, заключившее договор перевозки пассажира (статья 10).

Полагаем, что данное определение в Уставе, достаточно лаконичное, не в полной мере отражает содержание юридического механизма понятия. Законодателем в Уставе не сформулировано понятие «пассажирские перевозки», которое определено только в литературе, как - перемещение людей и багажа средствами транспорта. Данное обстоятельство необходимо исправить, изучив вопросы содержания понятий «пассажирской перевозки» и «пассажир».

Рассмотрим алгоритм железнодорожной пассажирской перевозки, состоящий из шести этапов.

Первый: нахождение физического лица (пассажира) на вокзале для приобретения проездного документа (билета).

Второй: заключение в устной, возмездной форме договора перевозки пассажира - приобретение поездного документа (билета) в железнодорожной кассе вокзала, в соответствие со статьей 786 (Договор перевозки пассажира) Гражданского кодекса РФ. 
Третий: нахождение пассажира на территории железнодорожной станции, железнодорожного вокзала, привокзальной площади или пассажирской платформы в ожидании транспортного средства, с помощью которого будет осуществлена железнодорожная перевозка.

Четвертый: проезд пассажира поездом от станции отправления до станции значения железнодорожным транспортом.

Пятый: нахождение пассажира на территории железнодорожной станции, железнодорожного вокзала, привокзальной площади или пассажирской платформы после поездки.

Шестой: получение пассажиром на вокзале (если в этом есть необходимость) багажа, грузобагажа, либо при решении вопросов, связанных с ранее совершенной (предполагаемой) поездкой железнодорожным транспортом (розыск утраченного багажа, получение справочной информации и т.п.).

Анализируя вышеназванные этапы можно выделить три обязательных основные элемента понятий «пассажирской перевозки» и «пассажир»:

1) главный элемент - физическое лицо (пассажир), заключивший договор перевозки и имеющий перевозочный документ (билет) на предстоящую (совершенную) поездку на железнодорожном транспорте;

2) сопутствующий элемент - пассажир обязательно должен намереваться, совершить, либо он уже совершил поездку на железнодорожном транспорте;

3) сопутствующий элемент - пассажир должен находиться в железнодорожном транспортном средстве (вагоне), для совершения поездки или покидая транспорт после поездки, либо находиться в окружении железнодорожного объекта (станции, вокзала, привокзальной площади, пассажирской платформы).

Только при наличии всех вышеперечисленных элементов можно физическое лицо именовать «пассажиром» железнодорожного транспорта. Действующая законодательная редакция данного понятия содержит только главный элемент, а два других обязательных элемента не указаны, что является не допустимым и не раскрывает сущность понятия.

В настоящее время реально присутствует необходимость в законодательной корректировке действующего понятия «пассажир», путем предложения текста редакции, отвечающего необходимым требованиям.

Отношения между пассажиром, перевозчиками и другими участниками перевозочного процесса регулируются нормативными правовыми актами России и в первую очередь Правилами оказания услуг по перевозкам на железнодорожном транспорте пассажиров, а также как потребители, пассажиры пользуются всеми правами, предусмотренными законодательством Российской Федерации о защите прав потребителей.

Рассмотрим мнения ведущих ученых семасиологов по этимологии понятия «пассажир» на железнодорожном транспорте.

Поддерживаем мнение Тихомировой Л. В. и Тихомирова М.Ю., что пассажир потребитель транспортных услуг, связанных с перемещением физического лица на любом виде транспорта, заключивший договор на перевозку.

Заслуживает внимание мнение Иванниковой Е.А, что пассажир - тот, кто совершает поездку на поезде, пароходе, самолете и т.п.

Согласны с мнением Волина Б.М. и Ушакова Д.Н., что пассажир (от франц. passager) - человек совершающий поездку в поезде, на пароходе и т.п., проезжающий.

Разделяем позицию Ожегова С.И., что пассажир - человек, который совершает поездку на поезде, пароходе или ином виде транспорта.

Все вышеназванные ученые выдвигают единую точку зрения, что пассажир это лицо совершающий поездку или находящийся на территории железнодорожного объекта (станции, вокзала, пассажирской платформы, привокзальной площади). 
Рассматриваемое понятие «пассажир» было принято законодателем 14.06. 2012 года, т.е. спустя более девяти лет после принятия Устава (10.01.2003 г.), в связи с тем, что у правоприменителей (работников железной дороги и правоохранительных органов - МВД РФ, ФСБ РФ, Прокуратуры РФ, Следственного комитета РФ, судебных органов РФ и др.) при отсутствии определения понятия «пассажир» стали возникать различные коллизионные вопросы, при разрешения различных проблемных ситуаций и судебных дел при перевозке пассажиров.

Верховный Суд РФ был вынужден принять (20.10. 2011 г., до принятия существующей редакции) судебное решение - прецедент следующего содержания: «Так, Устав определяет пассажира как лицо, совершающее поездку в поезде по действительному проездному документу (билету) либо имеющее проездной документ (билет) и находящееся на территории железнодорожной станции, железнодорожного вокзала или пассажирской платформы непосредственно перед указанной поездкой или непосредственно после нее». Возможно, что принятие данного судебного решения, явилось основной побудительной причиной появления законодательного понятия «пассажир» в Уставе.

C учетом вышеизложенного, предлагаем внести в статью 2 Устава железнодорожного транспорта Российской Федерации вместо старой редакции понятия «пассажир», между понятиями «тарифные руководства» и «железнодорожная станция», новую редакцию следующего содержания:

«пассажир - физическое лицо, совершающее поездку в поезде по действующему проездному документу (билету), либо имеющее проездной документ (билет) и находящееся на территории железнодорожной станции, железнодорожного вокзала, привокзальной территории или пассажирской платформе, непосредственно перед поездкой или непосредственно после нее».

Кроме того, предлагаем внести в текст статьи 2 Устава, после скорректированного понятия «пассажир», новую редакцию понятия «пассажирские железнодорожные перевозки» следующего содержания:

«пассажирские железнодорожные перевозки - перемещение физических или юридических лиц железнодорожным транспортом в пределах территории Российской Федерации, по заключенным договорам перевозки пассажиров, багажа и грузобагажа».

Принятие новых понятий в редакцию Устава железнодорожного транспорта Российской Федерации позволит работникам железнодорожного транспорта и правоохранительным органам России решать на более качественном уровне возложенные на них профессиональные задачи.

$$
* * *
$$

1. Большая энциклопедия транспорта: В 8 т. Том 4. Железнодорожный транспорт / Главный редактор Н.С. Конарев. - М.: Большая Русская энциклопедия, 2003. -744 с.

2. История организации и управления железнодорожным транспортом России. Факты, события, люди. К 200-летию транспортного ведомства и образования на транспорте России / Под ред. А.А. Тимошина. - М.: ГОУ «Учебно-методический центр по образованию на железнодорожном транспорте», 2009. -200c.

3. Устав железнодорожного транспорта Российской Федерации// Собрание законодательства Российской Федерации, 2003, № 2, ст.170.

4. Федеральный закон от 14.06.2012 г. № 78-Ф3 «О внесении изменений в отдельные законодательные акты РФ в связи с принятием Федерального закона «Об обязательном страховании гражданской ответственности перевозчика за причинение вреда жизни, здоровью, имуществу пассажиров и о порядке возмещения такого вреда, причиненного при перевозках пассажиров метрополитеном»// www.consultant.ru.

5. Железнодорожный транспорт: Энциклопедия / Гл. ред. Н.С. Конарев. - М.: Большая Русская энциклопедия, 1994. -291 с.

6. Гражданский кодекс Российской Федерации. Часть 2// Собрание законодательства Российской Федерации, 1996, № 5, ст.410.

7. Правила оказания услуг по перевозкам на железнодорожном транспорте пассажиров, а также грузов, багажа и грузобагажа для личных, семейных, домашних и иных нужд, не связанных с 
осуществлением предпринимательской деятельности //Собрание законодательства Российской Федерации, 2005, № 10, ст.851.

8. Закон Российской Федерации «О защите прав потребителей»// Собрание законодательства Российской Федерации, 1996, № 3, ст.140.

9. Тихомирова Л.В., Тихомиров М.Ю. Юридическая энциклопедия. Издание 6-е, дополненное и переработанное / Под ред. М.Ю. Тихомирова. 2008. - 677с.

10. Словарь русского языка в четырех томах. Том III. Ред. Е.А. Иванникова. Академия наук СССР. Институт русского языка. - М.: Издательство «Русский язык». 1983. - 298с.

11. Толковый словарь русского языка. Гл. ред. Б.М. Волин, Д.Н. Ушаков. Том III. Государственное издательство иностранных и национальных словарей.- М.: 1939. - 620с.

12. Ожегов С.И. Словарь русского языка: Ок. 57000 слов/ Под ред. докт. филол. наук, проф. Н.Ю. Швецовой. - 15-е изд., стереотип. - М.: Рус.яз. 1984. - 436 с.

13. Определение Верховного Суда РФ от 20.10.2011 г. № КАС11-542 //www. consultant. ru.

\section{Парфёнова А.И., Шергунова Е.А. \\ Машино-место - нововведение гражданского законодательства}

Юго-Западный государственный университет (Россия, Курск)

doi:10.18411/spc-20-11-2017-12

idsp: 000001:spc-20-11-2017-12

С 1 января 2017 года вступил в силу Федеральный закон от 03.07.2016 № 315Ф3 «О внесении изменений в часть первую Гражданского кодекса Российской Федерации и отдельный законодательные акты Российской Федерации» (далее Федеральный закон от 03.07.2016 № 315-Ф3).

Одним из нововведений Федерального закона от 03.07.2016 № 315-ФЗ является признание машино-мест самостоятельными объектами гражданского оборота. Соответственно, машино-место может быть предметом договора купли-продажи, аренды, передаваться по наследству, быть объектом залога. Кроме того, с 1 января 2017 года право собственности на машино-место подлежит государственной регистрации в соответствии с Федеральным законом от 13.05.2015 № 218-Ф3 «О государственной регистрации недвижимости» (далее - Закон о регистрации).

Понятие машино-места как объекта недвижимого имущества раскрывается в абз. 3 ч. 1 статьи 130 Гражданского Кодекса Российской Федерации (далее - ГК РФ): к недвижимым вещам относятся предназначенные для размещения транспортных средств части зданий или сооружений (машино-места), если границы таких помещений, частей зданий или сооружений описаны в установленном законодательством о государственном кадастровом учете порядке.

Аналогичное понятие машино-места прописано в п. 29 статьи 1 Градостроительного Кодекса РФ.

В соответствии с частями 6.1, 6.2 статьи 24 Закона о регистрации местоположение машино-места устанавливается посредством графического отображения на плане этажа или части этажа здания либо сооружения (при отсутствии этажности у здания либо сооружения - на плане здания либо сооружения) геометрической фигуры, соответствующей границам машино-места. Границы машиноместа определяются проектной документацией здания, сооружения и обозначаются или закрепляются лицом, осуществляющим строительство или эксплуатацию здания, сооружения, либо обладателем права на машино-место, в том числе путем нанесения на поверхность пола или кровли разметки (краской, с использованием наклеек или иными способами). Границы машино-места на этаже (при отсутствии этажности - в здании или сооружении) устанавливаются либо восстанавливаются путем определения расстояния от не менее двух точек, находящихся в прямой видимости и закрепленных долговременными специальными метками на внутренней поверхности строительных конструкций этажа (стенах, перегородках, колоннах, на поверхности пола, до 